\section{RAUSP}

54,1

\section{4}

Received 8 September 2017 Accepted 7 May 2018

\title{
Effects of the management control system in unethical behaviors
}

\author{
Luciana Klein
}

Universidade Federal do Parana, Curitiba, Brazil

Ilse Maria Beuren

Programa de Pós-Graduação em Contabilidade da Universidade Federal de Santa

Catarina-UFSC, Universidade Federal de Santa Catarina,

Florianopolis, Brazil, and

Delci Dal Vesco

\author{
CCSA, Universidade Estadual do Oeste do Parana, Cascavel, Brazil
}

\begin{abstract}
Purpose - This study investigates which dimensions of the management control system (MCS) increase the perception of organizational justice and reduce unethical behavior in the perception of managers. The purpose of this paper is to validate the theoretical model of the study of Langevin and Mendoza (2012), testing the theoretical hypotheses formulated by the authors.

Design/methodology/approach - A survey was performed in companies listed among the Best and Largest of Exame Magazine, and the sample is composed of 102 respondents of the research, which consists of 41 assertions.

Findings - The results of the structural equation modeling show that the definition of objectives increases the perception of procedural justice, but the same was not observed regarding the remuneration of the managers. Likewise, disregarding aspects that are uncontrollable by managers in performance evaluation does not lead to the perception of procedural and distributive justice. However, feedback quality leads to the understanding that the MCS is fair. Perception of procedural and distributive justice was also observed in the use of multiple measures of performance by the company.

Research limitations/implications - Other factors that have not been investigated may interfere with and contribute to the reduction of unethical behavior (budget slack and data manipulation).

Originality/value - The only variable that interferes in the reduction of unethical behavior is feedback quality. The non-confirmation of all the hypotheses instigates the replication of the research in other contexts for empirical validation of the theoretical model of Langevin and Mendoza (2012).
\end{abstract}

Keywords Organizational justice, Budgetary slack, Data manipulation, Management control system, Unethical behaviors

Paper type Research paper

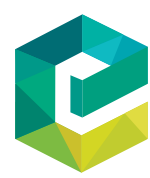

\section{Introduction}

Organizational justice is socially constructed and influences people's attitudes and behaviors in the workplace (Folger and Konovsky, 1989). Omar (2006) mentions that

(C) Luciana Klein, Ilse Maria Beuren and Delci Dal Vesco. Published in RAUSP Management Journal. Published by Emerald Publishing Limited. This article is published under the Creative Commons Attribution (CC BY 4.0) licence. Anyone may reproduce, distribute, translate and create derivative works of this article (for both commercial and non-commercial purposes), subject to full attribution to the original publication and authors. The full terms of this licence may be seen at http://creativecommons.org/licences/by/4.0/legalcode 
organizational justice refers to employees' perceptions of what they consider fair or unfair in their work environment. Therefore, organizational justice, also referred to as organizational fairness, is understood as the fairness perceived by the employees regarding the work relations within the organization.

Research studies have been conducted to identify how it happens, which elements promote feelings of injustice, and what the main reactions of individuals are. Langevin and Mendoza (2012) emphasize that, if the management control system (MCS) is considered unfair, it can lead managers to behave in a way that is harmful to the organization. For example, it may lead managers to have unethical behaviors (Langevin and Mendoza, 2012), such as propensity to create budgetary slack (Onsi, 1973; Merchant, 1985; Dunk, 1993) and manipulate data (Merchant and Rockness, 1994).

The first unethical behavior, creation of budgetary slack, is considered by Merchant (1985) as the difference between the amount budgeted and the amount really necessary to meet the forecasted needs, i.e. it represents the slack as the excess resources requested to execute a task. In this way, budgetary slack can be understood as intentional underestimation of productive capacities and overestimation of spending in a budget (Libby, 2003; Anthony and Govindarajan, 2006).

The second unethical behavior, data manipulation, is associated to the assessment of the managers' performance. MCSs include performance measurement mechanisms that organizations use to verify whether the results are aligned with the objectives and to assess managers' performance. In this process, managers can try to build a favorable self-image, different from the real one, with a tendency to manipulate the performance indicators (Merchant and Van Der Stede, 2007). Data manipulation can occur through falsification, which involves providing erroneous data or managing the results, which is any action of managers that affects the result and does not represent the economic situation of the organization (Merchant and Rockness, 1994).

For Ackroyd and Thompson (1999), unethical behavior cannot be tackled, at least not with the traditional means of coercion and forced incentives. However, over the past decade, some MCS researchers have begun to use the knowledge provided by research studies on organizational justice (Cohen-Charash and Spector, 2001; Colquitt et al., 2001) and identified that these unethical behaviors can be reduced when MCSs are perceived to be fair (Little et al., 2002; Wentzel, 2004; Staley and Magner, 2007).

Langevin and Mendoza (2012) identified four critical characteristics that need to be observed in relation to MCS:

(1) the opportunity given to managers to participate in setting objectives;

(2) application of the controllability principle in setting objectives or in the performance assessment;

(3) quality of feedback; and

(4) use of multiple measures of performance.

They all represent key dimensions of MCS, i.e. they characterize how the objectives are defined, the results are measured and performance is assessed. These characteristics can be reflected in the perception of organizational justice and in the individuals' attitudes and behaviors.

In this perspective, Langevin and Mendoza (2012) constructed a theoretical framework regarding the effects of MCS on unethical behaviors through perceived organizational justice, organizational commitment and trust in the supervisor to identify: 
RAUSP

54,1

- what characteristics of MCS increase perceived impartiality; and

- how the perception of MCS's justice reduces managers' propensity to create budgetary slack and manipulate data.

In the theoretical model, they propose, initially, to test the association of the mentioned characteristics of MCS with organizational justice (distributive, procedural and interactional). Then, to test the association of perception of organizational justice with unethical behaviors, in this case, the creation of budgetary slack with the increase of organizational commitment, and data manipulation with the increase of trust in the supervisor.

However, Langevin and Mendoza (2012) warn that this theoretical model still needs to be empirically tested, which reveals a research gap. The present study seeks to validate the theoretical model of Langevin and Mendoza's (2012) study, testing the theoretical hypotheses formulated by the authors, which they didn't test empirically. Thus, the question that guides this study is: Which MCS dimensions indicated by Langevin and Mendoza (2012) raise the perception of organizational justice and reduce managers' unethical behavior (creation of budgetary slack and data manipulation)?

In the past two decades, there has been a large number of scandals in the business world, many of them in different ways related to accounting and management control (CugueróEscofet and Rosanas, 2017). These authors warn that it is relevant to understand the dysfunctional effects of measurement systems and incentives, and the possible ways to overcome such dysfunctional effects. Thus, searching for explanations for possible unethical behaviors in relation to MCS components in large Brazilian companies is interesting, since this may be one of the origins of many of the scandals.

In this sense, the objective is to contribute to the development of this field of research from the perspective of the managerial accounting, by addressing aspects of MCS associated with perception of organizational justice, organizational commitment and trust in the supervisor and the reflexes in the creation of budgetary slack and data manipulation. These aspects are important because these behaviors distort the processes of planning and performance measurement and may lead managers to make decisions that are contrary to the interests of the organization, as well as generating unnecessary costs and rewards that are detrimental to the organization (Langevin and Mendoza, 2012).

\section{Theoretical framework}

\subsection{Perception of organizational justice in the management control system}

An act is only fair because someone perceives it to be so (Fortin, 2008). In a research on justice conducted by Mikula (1980), the work environment was one of the places of social coexistence that presented the largest number of events considered unfair. Colquitt (2001) warns that injustices in the workplace can trigger stress, burnout, loss of commitment, absenteeism and other individual and organizational problems. For Cohen-Charash and Spector (2001), injustices in the workplace affect employees' behavior because, in addition to reducing their satisfaction and performance, they worsen feelings about the company, can harm the health of the individual and compromise the results of the organization.

Organizational justice is usually approached in the literature in three dimensions: distributive, procedural and interactional (Sotomayor, 2007; Beuren et al., 2016a, 2016b, 2016c). The latter is divided by some authors into informational and interpersonal (Greenberg, 1993). Distributive justice refers to the perceptions of employees' justice in what they receive from the organization, having as a parameter the equity between individuals (Folger and Cropanzano, 1998). Procedural justice refers to the employees' perceptions of justice in the procedures adopted in the organizational processes (Leventhal, 1980). 
Interaction justice refers to the employees' perceptions of justice in the interpersonal, procedural or procedural aspects and is divided in informational and interpersonal. Informational refers to the explanations provided to the employees (Colquitt et al., 2001). Interpersonal refers to the degree of courtesy, dignity and respect with which they are treated by superiors (Colquitt et al., 2001).

Chenhall (2003) argues that it seems likely that issues associated to organizational justice, commitment and trust can help explain how individuals react to information. In general, the results of the research studies indicate that the perceptions of organizational Management control system justice affect a wide range of organizational attitudes and behaviors and can interact with each other in explaining these same attitudes and behaviors (Colquitt, 2001; Rego and Souto, 2004; Sotomayor, 2007; Maia, 2013; Beuren et al., 2016a). Among them, the creation of budgetary slack and data manipulation, unethical behaviors highlighted by Langevin and Mendoza (2012), are important in this study.

Research studies on the relationship between unethical behavior and organizational justice indicate that the propensity to create budgetary slack is reduced when the procedures and the enactment of decisions are considered fair (Little et al., 2002; Wentzel, 2004). Staley and Magner (2007) demonstrated how procedural and interactional justice reduces managers' propensity to create budgetary slack, enhancing trust in the supervisor. However, no research has been found that seeks to identify the relationship between organizational justice and data manipulation and not even whether MCS reduces unethical behavior when there is a greater perception of organizational justice.

MCS can be a facilitating mechanism for the adoption of business strategies and one of the main artifacts of the management process. Anthony (1965) understands managerial control as an explicit and formalized mechanism that contributes to the company achieving maximum efficiency and effectiveness, given that the purpose of the system is to promote the alignment between the objectives, so that personal purposes coincide with business' purposes. They include all the mechanisms that managers use to ensure that their subordinates present behaviors and make decisions that are consistent with the organization's objectives and strategies (Anthony and Govindarajan, 2006; Merchant and Van Der Stede, 2007).

The focus of Anthony's (1965) conceptualization of managerial control is to stimulate individual performance through financial rewards without considering the values and ideas of people in the design of MCS. On the other hand, Flamholtz (1979) understands managerial control as the process of influencing the behavior of the members of the organization, in order for people to behave in a way that favors the achievement of the organizational objectives. It is not about controlling people's behavior, but influencing them to act in line with the organization's predetermined goals.

Simons (1995) proposed a theoretical model of MCS with four levers: belief systems, boundary systems, diagnostic control systems and interactive control systems. According to Henri (2006), the construction of these four levers is because of the fact that MCS generates dynamic tensions, since managers need to achieve organizational objectives that may be conflicting, and the idea is that the four levers help in balancing these tensions, producing adequate balance.

Therefore, managers are affected by the design and use of MCSs and this is reflected in the managers' perception of justice (Langevin and Mendoza, 2012). For these authors, MCS is linked to issues of distributive justice, because the underlying financial results, whether in determining objectives or allocating resources, affect managers' rewards. It is also related to aspects of procedural justice, because setting objectives, performance assessment and establishing rewards depend on procedures (Beuren et al., 2016c). MCS can also affect 
RAUSP

54,1

interactional justice, particularly in the interaction of subordinates with their superiors, in negotiating budgetary goals, in evaluating performance, and in establishing rewards (Langevin and Mendoza, 2012).

\subsection{Unethical behavior: creation of budgetary slack and data manipulation}

Ethical behaviors can be defined as those that, at the same time, are legal and acceptable to organizations (Jones, 1991). This study focuses on two behaviors that may be considered unethical: creation of budgetary slack and data manipulation. According to Langevin and Mendoza (2012), these two types of unethical behaviors are widely observed in organizations.

Budgetary slack occurs when the manager, without the consent of his superiors, overestimates the expenses, underestimates the revenues and overestimates the demand for resources under his responsibility (Davis et al., 2006), aiming at self-satisfaction in the remuneration process for results related to the budget (Onsi, 1973; Libby, 2003; Beuren et al., 2015b). According to Cyert and March (1963), this is a manager's dysfunctional behavior in the budgetary process.

Hopwood (1972) found in his research that managers assessed only based on the budget are more likely to create budgetary slack, than when using multiple assessment systems. For the author, the creation of slack occurs basically to fulfill the forecasted budget. In this sense, Dunk (1993) and Lavarda and Fank (2014) warn that the main argument for managers to create slack in their budgets is to improve the prospects of their performancebased remuneration.

Data manipulation, in turn, is seen as unethical behavior when aiming at personal advantages (Merchant and Van Der Stede, 2007). Condé (2013) points out that to reduce the failures of internal control that trigger data manipulation, some issues require attention, such as verifying why a person practices a specific action to distort the company's results, while another, in a similar situation, does not practice such action or practices different action, with the same purpose.

According to Merchant (1985), employees of companies, regardless of their position, are prone to make decisions that serve their own interests, to the detriment of the organization, in accordance with the conflict of interests between principal and agent, as advocated in agency theory. The author explains that managers, for example, can manipulate the performance reports of their department to present better results, even knowing that the information reported is untrue and, in many cases, may even harm the organization.

Langevin and Mendoza (2012) argue that the perceived justice in the company's MCS can be a mechanism to reduce the creation of these unethical behaviors. Cugueró-Escofet and Rosanas (2017) argue that the perceived justice in the design and use of MCS may be formal and/or informal and investigated the prominence of both through case studies. They concluded that, in any case, it is a necessary condition for the congruence of the objectives of the individuals and the organization, their stability over time, besides the ethical behavior that the system with these characteristics can generate in the organization.

Whether the perceived justice is formal or informal, the distributive, procedural and interactional justices interact to form a global judgment of the process and, from this, managers can perceive it as globally fair and, thus, less likely to create budgetary slack and manipulate data. Therefore, it is important to verify empirically if the perception of organizational justice in MCS reduces unethical behavior, in the view of the company's managers. In this perspective, the objective is to test empirically the theoretical hypotheses proposed in the study by Langevin and Mendoza (2012). Thus, a synthesis of the study of 
these authors, with a view to contextualize the formulation of theoretical hypotheses, is presented below.

\subsection{Study of Langevin and Mendoza (2012)}

Langevin and Mendoza (2012) constructed a general framework based on the theoretical results of their research to identify the dimensions of MCS that increase perceived impartiality and how the perception of justice of MCS reduces the propensity of managers to create budgetary slack and manipulate data. The authors identified four critical characteristics or key dimensions of MCS: managers' participation in setting goals, controllability principle, quality feedback and multiple measures of performance.

The first key dimension of MCS increases the perception of procedural justice in function of the alignment with the procedural rules proposed by Leventhal et al. (1980), as the participation:

- $\quad$ serves as a means of communication between subordinates and superiors, allowing subordinates to exchange and seek information with their superiors, which tends to improve the accuracy of the data used in the decision-making process;

- allows subordinates to voice their complaints and correct any prior inadequate beliefs of their superiors;

- allows subordinates to expose their concerns and values, which favors representativeness; and

- satisfies the criterion of ethics, since it is consistent with the moral value that people have the opportunity to be involved in setting goals.

According to Langevin and Mendoza (2012), the perception of distributive justice also increases when managers are heard, because participation gives managers the opportunity to influence their objectives, as well as the amount of resources that will be allocated to them. In addition, participation gives them the opportunity to influence the objectives, which will then be used as a reference for their assessment. Thus, participation can increase the chances that managers will receive fair rewards, as they will depend on the targets they helped to set.

The second key dimension of MCS predicts that managers should be assessed only based on what they can control. Langevin and Mendoza (2012) argue that the controllability principle meets most of the procedural rules set forth by Leventhal et al. (1980). First, the removal of uncontrollable factors from targets and assessments indicates that the performance measurement will be tied to the managers' efforts rather than to events beyond their control. Second, the controllability principle allows greater consistency in procedures of performance assessment. Third, the implementation of the controllability principle implies neutralization of uncontrollable factors that could affect the results of the assessed ones. Fourth, the controllability principle is in line with the ethical criteria, under the argument of Merchant and Van Der Stede (2000), of being more ethical not to penalize managers for results adversely affected by uncontrollable events.

The third key dimension of the MCS regards to the perception of procedural justice is the quality of feedback (Cohen-Charash and Spector, 2001). Consistency and precision, two rules of Leventhal et al. (1980), are the main features of the quality of the performance feedback (Hartmann and Slapnicar, 2009). Quality feedback also affects interactional justice. According to Colquitt and Jackson (2006), providing quality feedback favors approachability and encourages communication between managers and their superiors. Therefore, it contributes to promote informational justice, which is one of the two 
RAUSP

54,1

components of interpersonal justice. In addition, superiors who discuss the results with their subordinates are considered as being more respectful. Quality feedback may indicate that subordinates are valued as members of the group.

The fourth key dimension pointed out by Langevin and Mendoza (2012) is the adoption of multiple measures of performance, which affect more the distributive justice by measuring more accurately the actual performance. The use of multiple performance indicators provides greater accuracy in comparing performance indicators with organizational results, and this is reflected in the employees' greater perceptions of distributive justice (Burke et al., 2009). The use of multiple non-financial measures can also contribute to increase the perception of procedural justice of MCS, as the accuracy of the information is a relevant criterion of procedural justice (Leventhal, 1980).

Research studies (Cohen-Charash and Spector, 2001; Colquitt et al., 2001; Jesus and Rowe, 2015; Dal Vesco et al., 2016) show that greater perception of justice has positive impact on the behavior of employees in relation to the organization, because it results in greater satisfaction at work, trust in the supervisor, commitment and organizational citizenship behavior, besides reducing stress. Among the positive effects of perceived justice, organizational commitment and trust in the supervisor, according to Langevin and Mendoza (2012), are useful in explaining the relationship between MCS perceived as fair and the reduction of unethical behaviors.

According to Mowday et al. (1979), when managers are committed to the organization for which they work, they will tend less to make decisions that could harm it. Nouri and Parker (1996) found that high level of commitment is associated with decrease in the level of budgetary slack. Therefore, the perceived justice of MCS is reflected in greater organizational commitment, thus reducing the propensity of managers to create budgetary slack and manipulate data.

Trust in the superior conveys greater meaning to the managers' perception of control over results. This perception of control is an essential component of organizational justice (Folger and Greenberg, 1985). If subordinates trust their superiors, they will be less likely to develop unethical behaviors, as it is argued that trust implies in the expectation that the other party will act kindly (Whitener et al., 1998).

Based on the above, Langevin and Mendoza (2012) elaborated the theoretical hypotheses presented in Table I. In the first six hypotheses, the intention was to verify which characteristics of MCS increase the managers' perception to consider it fair. In the following five hypotheses, they sought to verify the reasons why MCS is understood as fair, contributing to the reduction of managers' propensity to create budgetary slack or manipulate the data.

According to Table I, Langevin and Mendoza (2012) suggest that the two attitudinal outcomes (organizational commitment and trust in the superior) help explain why perceptions of justice in MCS reduce unethical behavior. The assumption is that the perception of organizational justice in the MCS operates on two levels; it:

(1) affects the relationship between the employee and the organization as a whole (organizational commitment); and

(2) influences the relationship with the superior (trust in the superior).

And the two attitudinal variables, in turn, reduce the propensity of employees to adopt unethical behavior. Figure 1 illustrates these relationships proposed by the authors.

Because of the limitations of the study, Langevin and Mendoza (2012) emphasized that the first step necessary is the test of the theoretical hypotheses proposed. Thus, the purpose 


\begin{tabular}{ll} 
Hypotheses & Description \\
\hline$H 1 a$ & Participation in setting objectives increases the procedural justice perceived in MCS \\
$H 1 b$ & Participation in setting objectives increases the perceived distributive justice in MCS \\
$H 2 a$ & Application of the controllability principle increases the perceived distributive justice in \\
& MCS \\
$H 2 b$ & Application of the controllability principle increases the procedural justice perceived in MCS \\
$H 3 a$ & Quality of feedback increases the procedural justice perceived in MCS \\
$H 3 b$ & Quality of feedback enhances perceived interactional justice in MCS \\
$H 4 a$ & Use of multiple non-financial performance indicators increases the perceived distributive \\
$H 4 b$ & justice in MCS \\
Use of multiple non-financial performance indicators increases the procedural justice \\
perceived in MCS
\end{tabular}

Source: Prepared based on Langevin and Mendoza (2012)
Management
control system

61

Table I.

Theoretical

hypotheses proposed

by Langevin and

Mendoza (2012)

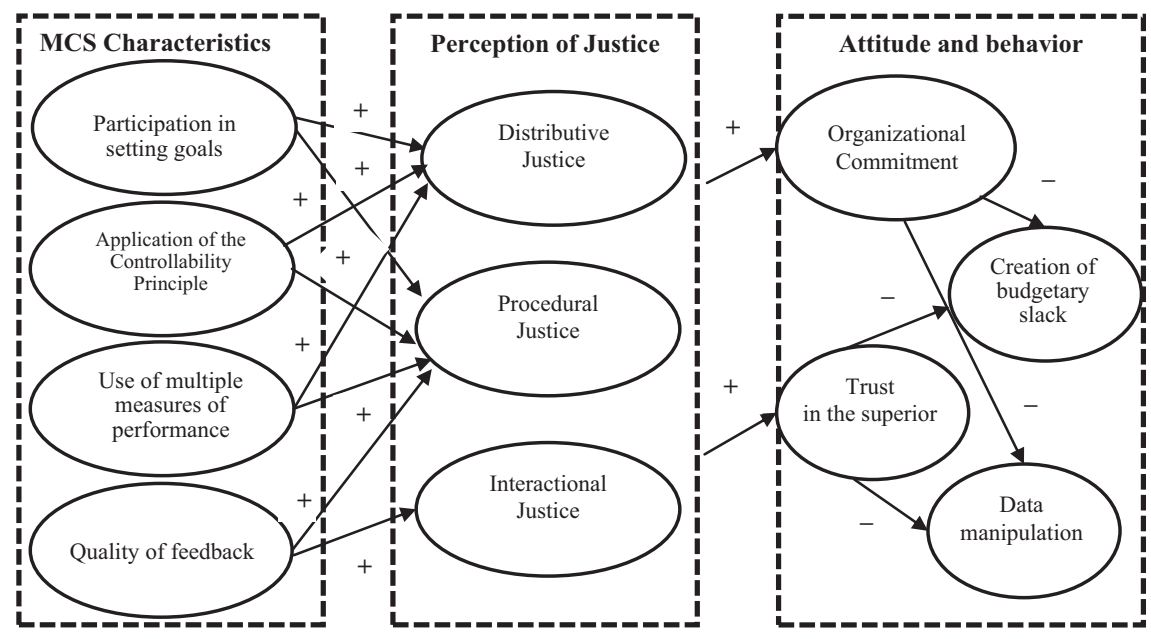

Source: Langevin and Mendoza (2012, p. 218)

Figure 1.

Effects of MCS on unethical behavior through perceived organizational justice, organizational commitment, and trust in the superior

of this research is to test them empirically to verify whether the perception of organizational justice in MCS reduces unethical behavior in large Brazilian companies.

\section{Research methodology}

This descriptive research was carried out based on a survey that had as population the 500 companies listed among the Best and Largest of Exame Magazine, edition of 2014. The 
RAUSP

54,1

option for this population stems from the fact that large companies tend to have a consolidated MCS and division by areas of responsibility, which is essential to operationalize the purpose of this study. The research subjects are composed of the managers of these companies.

To estimate the minimum sample size, G*Power 3.1.9 software was used (Faul et al., 2009). As recommended by Cohen (1988), the power of the test was used at 0.80 and the median $\mathrm{f} 2$ was 0.15 . Considering the number of four predictors (Figure 1 ) and that, for PLS, it is the one that defines the minimum sample size, the result of the software pointed out that the minimum number is 85 cases. The nonrandom sample consisted of the 102 managers who responded the research instrument; thus, it is adequate to estimate the hypothesis of the research.

The research instrument comprised 41 assertions, based on studies developed by Dunk (1993), Rego (2002), Widener (2006), López et al. (2007), Hartmann and Slapnicar (2009), Burkert et al. (2011) and Langevin and Mendoza (2012), as shown in Table II.

In the research instrument, assertions were presented for each hypothesis, and managers were asked to indicate, in a seven-point scale, their degree of agreement $(1=$ totally disagree and $7=$ totally agree). The equality of points in the scale had the purpose of minimizing the problems of arbitrary weighting the categories of qualitative variables, as, according to Fávero et al. (2009), there is no logic that justifies the adoption of certain weights to the detriment of others. However, it is worth remembering that the scales and instruments used were consolidated by theory and applied/validated in previous studies. It is also important to highlight that the scores of the confirmatory factorial analysis were used, allowing to extract a new aggregate measure of the variables by weighing the scores of the respondents of each item by the factorial score of the variable, in each unit of the sample (Silva and Costa, 2014).

Google Docs was used for the preparation and sending of the research instrument. Before the application of the questionnaire, a pretest was carried out with three doctoral students, and some writing adjustments were made based on the suggestions presented and afterwards it was sent to the research subjects. The questionnaire was sent several times in the period from August to December, 2014.

The data were initially paired in the Statistical Analysis System (SAS) program, Windows 19. Structural equations modeling (SEM) was used to test the hypothesis. Partial least squares (PLS-PM) method was applied for the estimation of the structural equations model. The use of this method is justified by the fact that the PLS-PM meets the prediction objectives and also constructs theoretical models in a more exploratory than confirmatory sense, as there are no indicators of adjustment of the adequacy of the model as a whole (Bido et al., 2010).

The SEM-PLS model was analyzed in two sequential steps, the measurement model and the structural model (Hair et al., 2005). To apply structural equations it is assumed the use of continuous variables, but the use of categorical variables, including the Likert-type scale, is common. Ordinal scales violate some assumptions of SEM, such as continuity and normality. However, the simulations indicate that the results are reliable provided that at least five classes are used and that the distribution approaches normality (Bollen and Long, 1992).

Klem (2006) explains that the PLS technique allows testing a set of variables to investigate the level of explanation of the predictor variables to the dependent variables (multiple regression aspects) and indicates the most important predictor variable (factor analysis). It also allows to verify whether the theoretical model is valid, based on the real 


\begin{tabular}{|c|c|c|c|}
\hline Variables & Questions used from previous studies & Original scale ${ }^{*}$ & Mlanagement \\
\hline Organizational justice & $\begin{array}{l}\text { From Rego's (2002) questionnaire, for } \\
\text { organizational justice, only three of the } 17 \\
\text { assertions regarding the distributive } \\
\text { justice of tasks were used ( } 15 \text { to } 17 \text { ) }\end{array}$ & $\begin{array}{l}\text { Likert of } 6 \text { points ( } 1=\text { strongly } \\
\text { disagree and } 6=\text { strongly agree })\end{array}$ & \\
\hline $\begin{array}{l}\text { Organizational } \\
\text { Commitment }\end{array}$ & $\begin{array}{l}\text { From Rego's (2002) questionnaire, for } \\
\text { organizational commitment, all (three) } \\
\text { assertions were used }\end{array}$ & $\begin{array}{l}\text { Likert of } 6 \text { points }(1=\text { strongly } \\
\text { disagree and } 6=\text { strongly agree })\end{array}$ & 63 \\
\hline Trust in the superior & $\begin{array}{l}\text { From Hartmann and Slapnicar's ( } 2009 \\
\text { questionnaire), for trust in the superior, all } \\
\text { (three) the assertions of question } 7 \text { were } \\
\text { used }\end{array}$ & $\begin{array}{l}\text { Likert } 5 \text { points }(1=\text { totally disagree } \\
\text { and } 5=\text { totally agree })\end{array}$ & \\
\hline Budgetary slack & $\begin{array}{l}\text { From Dunk's (1993) questionnaire, from } \\
\text { the set of six assertions related to } \\
\text { budgetary slack, the three that were not } \\
\text { reverse-scaled were used }\end{array}$ & $\begin{array}{l}\text { Likert } 7 \text { points }(1=\text { totally disagree } \\
\text { and } 7=\text { totally agree })\end{array}$ & \\
\hline Data manipulation & $\begin{array}{l}\text { From Dunk's (1993) questionnaire, from } \\
\text { the set of six assertions related to } \\
\text { information asymmetry, the three most } \\
\text { pertinent to the possible manipulations of } \\
\text { the data were used }\end{array}$ & $\begin{array}{l}\text { Likert of } 7 \text { points }(1=\text { My superior } \ldots \\
\text { much better } \ldots \text { and } 7=\text { Me } \ldots \text { much } \\
\text { better ...) }\end{array}$ & \\
\hline Setting objectives & $\begin{array}{l}\text { From López, Stammerjohan, and McNair's } \\
\text { (2007) questionnaire, four of the six } \\
\text { assertions of the question about } \\
\text { budgetary participation were used, } \\
\text { replacing the term budget with goals and } \\
\text { objectives }\end{array}$ & $\begin{array}{l}\text { Likert } 7 \text { points }(1=\text { totally disagree } \\
\text { and } 7=\text { totally agree })\end{array}$ & \\
\hline $\begin{array}{l}\text { Controllability } \\
\text { principle }\end{array}$ & $\begin{array}{l}\text { From Burkert, Fischer and Schäffer's } \\
\text { (2011) questionnaire, the first three } \\
\text { assertions concerning the Controllability } \\
\text { Principle were used }\end{array}$ & $\begin{array}{l}\text { Likert of } 7 \text { points }(1=\text { a little and } 7= \\
\text { totally) }\end{array}$ & \\
\hline $\begin{array}{l}\text { Multiple measures of } \\
\text { performance }\end{array}$ & $\begin{array}{l}\text { The first assertion about multiple } \\
\text { performance measures was based on } \\
\text { Widener's (2006) study. One assertion } \\
\text { from Hartmann and Slapnicar's (2009) } \\
\text { questionnaire was used. The other two } \\
\text { assertions were based on Langevin and } \\
\text { Mendoza's (2012) study }\end{array}$ & $\begin{array}{l}\text { Likert } 7 \text { points }(1=\text { totally disagree } \\
\text { and } 7=\text { totally agree })\end{array}$ & \\
\hline Quality of feedback & $\begin{array}{l}\text { The four assertions of question } 5 \text { from } \\
\text { Hartmann and Slapnicar's ( } 2009 \text { ) } \\
\text { questionnaire were used for the quality of } \\
\text { feedback }\end{array}$ & $\begin{array}{l}\text { Likert } 5 \text { points }(1=\text { totally disagree } \\
\text { and } 5=\text { totally agree })\end{array}$ & \\
\hline \multicolumn{3}{|c|}{$\begin{array}{l}\text { Note: *To avoid differences in weights in the varied Likert scale in each variable, all scales were considered } \\
\text { as seven points, thus unifying the categories of the qualitative variables } \\
\text { Source: Own elaboration }\end{array}$} & $\begin{array}{l}\text { Table II. } \\
\text { Composition of the } \\
\text { research instrument }\end{array}$ \\
\hline
\end{tabular}

data observed (Hox and Bechger, 1998), and to simultaneously evaluate relationships among multiple constructs (Campana et al., 2009).

The use of PLS model is because of the fact that it allows the use of latent variables with formative indicators instead of reflective indicators (Hair et al., 2011). Formative indicators are those variables that form the construct and do not have correlation with each other, 
RAUSP

54,1

64

while the reflective ones are formed by the construct and measured by scales (Hair et al., 2011). The software SmartPLS version 2.00 was used.

\section{Description and analysis of results}

\subsection{Descriptive analysis}

Table III shows the descriptive analysis of the measures of minimum, maximum, median, mode, mean and standard deviation for the answers to the questions of the questionnaire.

It can be observed in Table III that the answers have certain linearity, with median varying between 3 and 6 , in the Likert scale of seven points, and mode between 4 and 7 . The mode result (5) for the assertive in reversal scale for Controllability Principle is surprising, as most respondents point out that their performance assessment includes aspects they cannot control. For Giraud et al. (2008), this principle is a prerequisite for establishing a sense of justice in relation to the performance assessment system. Therefore, managers may feel wronged in their performance assessment if there are no procedures to mitigate uncontrollable aspects, as observed in the mode (4) of the dimension of procedural justice. On the other hand, results for median (5) and mode (7) of the multiple measures of performance construct show that the performance assessments of respondents are anchored in objective information derived from MCS and subjective information is always substantiated. This is reflected in the perception of justice and in the managers' organizational commitment.

\subsection{Measurement model}

It is important to mention that the data of this research were collected through self-answered questionnaires. Podsakoff et al. (2003) warn that this method may lead to common method bias (CMB). Following the guidance of these authors, in relation to procedural techniques, the respondents were assured the anonymity of the participants and that the answers would be treated in an aggregate manner. Regarding the statistical technique, Harmans' singlefactor test was used, which, according to Podsakoff and Organ (1986), is the most commonly used method in the literature in general. If in the analysis a single factor or a general factor explains more than 50 per cent of variance of the variables, the $\mathrm{CMB}$ will be present, which did not occur in this study.

\begin{tabular}{lcccccc}
\hline Variables & Minimum & Maximum & Median & Mode & Mean & SD \\
\hline Distributive justice & 1 & 7 & 5 & 5 & 4.58 & 1.57 \\
Procedural justice & 1 & 7 & 4 & 4 & 4.12 & 1.79 \\
Interactional justice & 1 & 7 & 5 & 6 & 4.84 & 1.68 \\
Organizational commitment & 1 & 7 & 6 & 7 & 5.39 & 1.66 \\
Trust in the superior & 1 & 7 & 4 & 4 & 4.36 & 1.64 \\
Budgetary slack & 1 & 7 & 5 & 4 & 4.37 & 1.75 \\
Data Manipulation & 1 & 7 & 5 & 6 & 5.03 & 1.48 \\
Setting objectives & 1 & 7 & 5 & 6 & 4.91 & 1.59 \\
Controllability principle & 1 & 7 & 3 & 5 & 3.48 & 1,64 \\
Quality of Feedback & 1 & 7 & 4 & 5 & 4.53 & 2.02 \\
Multiple measures of performance & 1 & 7 & 5 & 7 & 3.89 & 1.86 \\
& & & & & &
\end{tabular}

Table III. 
After the control of the bias, the quality of the model was evaluated through composite reliability, Cronbach's alpha, convergent validity and discriminant validity. Table IV presents the adequacy indexes of the SEM-PLS model.

The composite reliability analysis of each construct has the function of evaluating whether the index adequately measured the constructs. Thus, the index should be greater than or equal to 0.70 (Hair et al., 2005). By the analysis of Table IV, the constructs budgetary slack and controllability principle presented lower indexes of 0.673 and 0.485 , respectively. Because of their importance for the structural model, it was decided to keep them in the research because the analysis was carried out considering the previous research studies and the original theoretical model.

This aspect can be justified by the fact that the theoretical model of Langevin and Mendoza (2012) has not been tested empirically yet, which in this case can contribute to the improvement of the research related to MCS, organizational justice and budgetary slack, as well as to the manipulation of data. Regarding the controllability principle, the construct was measured based on Burkert et al.'s (2011) model, already tested in 2011, but in another country (Germany) and with other theoretical dimensions.

For the internal consistency analysis (Cronbach's alpha), values from 0.60 were considered appropriate (Hair et al., 2005). Pasquali (2003) points out that when the number of items is small, this data should be relativized, since in this case the item under analysis substantially affects the total score, which may have occurred in the constructs budgetary slack and multiple measures of Performance, with, respectively, 0.576 and 0.560 , close to 0.60 . Thus, the indicators are considered to have adequately measured the constructs.

The convergent and discriminant validity of the constructs is evaluated by the average variance extracted, which should be higher than 0.50 (Hair et al., 2005). To perform the discriminant validity analysis, the criterion of Gaski and Nevin's (1985) study was used, which recommend that the comparisons of the composite reliability of each construct with correlations between the constructs should be smaller than their reliability. For the constructs studied, the discriminant validity between all dimensions was verified, as can be observed in Table V, where the composite reliability (diagonal, in bold) is perceived as greater than the correlation between the constructs.

\begin{tabular}{|c|c|c|c|c|c|c|c|}
\hline Constructs & AVE & $\begin{array}{l}\text { Composed } \\
\text { Reliability }\end{array}$ & $R^{2}$ & $\begin{array}{l}\text { Cronbach's } \\
\text { Alpha }\end{array}$ & Communality & Redundancy & \\
\hline Commitment & 0.885 & 0.958 & 0.466 & 0.935 & 0.885 & 0.188 & \\
\hline Trust & 0.851 & 0.945 & 0.661 & 0.912 & 0.851 & 0.198 & \\
\hline Setting objectives & 0.610 & 0.860 & 0.000 & 0.798 & 0.610 & 0.000 & \\
\hline Budgetary slack & 0.432 & 0.673 & 0.316 & 0.560 & 0.432 & 0.043 & \\
\hline Distributive justice & 0.849 & 0.965 & 0.299 & 0.955 & 0.849 & 0.094 & \\
\hline Interactional justice & 0.800 & 0.960 & 0.437 & 0.950 & 0.800 & 0.349 & \\
\hline Procedural justice & 0.789 & 0.918 & 0.541 & 0.867 & 0.789 & 0.236 & \\
\hline Data manipulation & 0.900 & 0.964 & 0.162 & 0.944 & 0.900 & -0.082 & \\
\hline $\begin{array}{l}\text { Multiple measures of } \\
\text { performance } \\
\text { Controllability }\end{array}$ & 0.534 & 0.772 & 0.000 & 0.576 & 0.534 & 0.000 & \\
\hline principle & 0.361 & 0.485 & 0.000 & 0.682 & 0.361 & 0.000 & Table II \\
\hline $\begin{array}{l}\text { Quality of feedback } \\
\text { Source: Research data }\end{array}$ & 0.824 & 0.933 & 0.000 & 0.894 & 0.824 & 0.000 & $\begin{array}{l}\text { Adequacy indexes of } \\
\text { the SEM-PLS model }\end{array}$ \\
\hline
\end{tabular}


RAUSP

54,1

66

Table V.

Discriminant validity

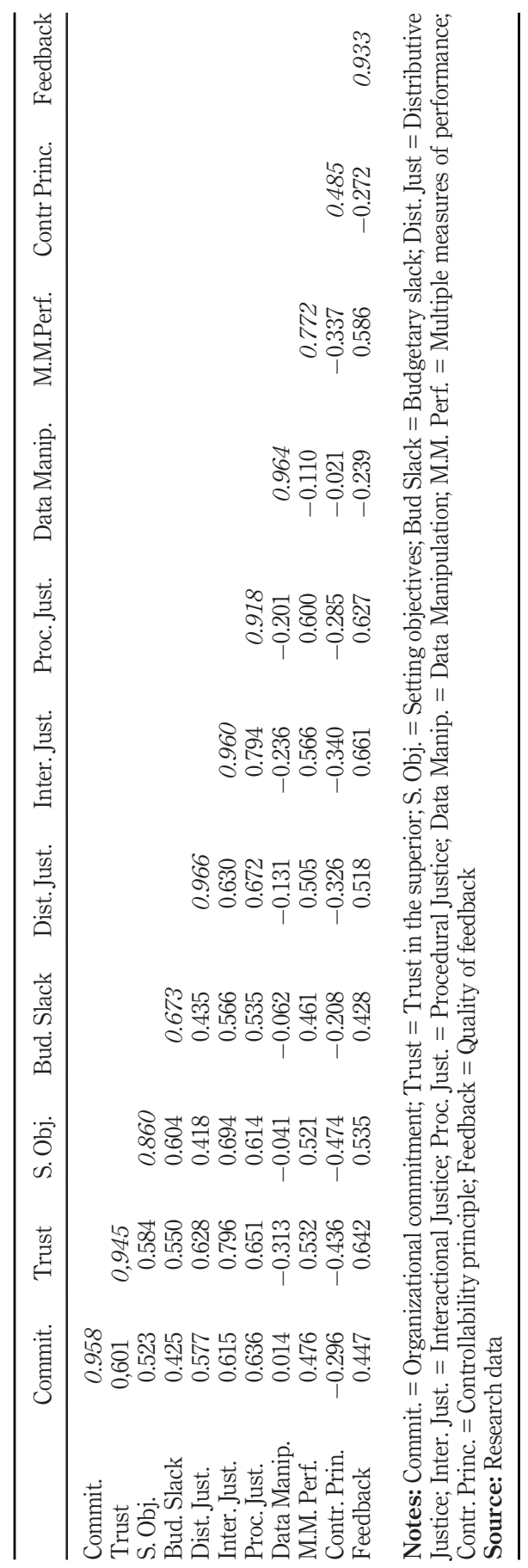


The next step, according to Hair et al. (2005), is to validate the structural model, which implies verifying $R^{2}$ values, i.e. the percentage of variance of a latent variable that is explained by other latent variables. $R^{2}$ values provide an adjustment measure for each structural equation, only for endogenous latent variables, being recommended values close to 1 . It can be seen in Table IV that the lowest $R^{2}$ among the constructs was 0.162 for the latent variable data manipulation. This result can be considered weak, but considering that the structural model is a theoretical model, not empirically investigated yet, the results can be admitted.

In summary, only the constructs budgetary slack, controllability principle and data manipulation were partially validated. On the other hand, only one of the constructs (data manipulation) did not meet the validation criterion of the structural model. In spite of that, this construct was maintained in the analysis, considering that it is a theoretical dimension of the structural model of Langevin and Mendoza (2012). However, more research is recommended given the constitutive and operational setting of this construct, which deals with data manipulation associated with ethical and moral factors.

\subsection{Structural model and hypothesis test}

After that, the hypothesis were tested for each path diagram of the structural model to identify whether the $t$-values were greater than 1.96 for $p<0.05$, as recommended by Hair et al. (2005). Table VI shows the direct effects, with the purpose of testing the hypotheses $H 1, H 2, H 3$ and H4. The results show that the relationship between setting objective and distributive justice, as well as controllability principle and distributive justice and controllability principle and procedural justice, did not present statistical significance.

The first hypothesis $(H 1 a)$ sought to verify whether participation in setting objectives is significantly related to procedural justice. The results were significant at $p<0.01$, i.e. when managers participate in setting objectives, business processes are considered fair. According to Langevin and Mendoza (2012), participation in setting objectives serves as a means of communication between subordinates and their superiors and allows subordinates to exchange and seek information with their superiors, which can improve the accuracy of the data used in the decision-making process. Participating in setting goals and objectives allows subordinates to express their opinions, participate proactively in the pursuit of continuous improvement and correct any superiors' inadequate previous beliefs, as well as satisfying the criterion of ethics, as it is consistent with the moral value that people should have the opportunity to get involved in setting goals.

\begin{tabular}{lcccc}
\hline Structural relationship & Beta direct effect & $t$-Test & Hypothesis & $p$-value \\
\hline S. Obj. $\rightarrow$ Proc. Just. & 0.334 & 3.407 & $H 1 a$ & $0.000^{\text {** }}$ \\
S. Obj. $\rightarrow$ Dist. Just. & 0.163 & 1.483 & $H 1 b$ & 0.138 \\
Contr. Prin. $\rightarrow$ Dist. Just. & -0.120 & 0.886 & $H 2 a$ & 0.376 \\
Contr. Prin. $\rightarrow$ Proc. Just. & 0.045 & 0.566 & $H 2 b$ & 0.571 \\
Feedback $\rightarrow$ Proc. Just. & 0.306 & 3.210 & $H 3 a$ & $0.001^{\text {** }}$ \\
Feedback $\rightarrow$ Inter. Just. & 0.661 & 10.290 & $H 3 b$ & $0.000^{\text {** }}$ \\
M.M. Perf. $\rightarrow$ Dist. Just. & 0.380 & 3.814 & $H 4 a$ & $0.000^{\text {** }}$ \\
M.M. Perf. $\rightarrow$ Proc. Just. & 0.261 & 2.902 & $H 4 b$ & $0.003^{* *}$
\end{tabular}

Notes: P.S.: *Significance $p<0,05 ; * *$ significance $p<0,01$

Source: Research data

Management control system

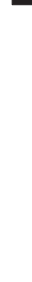


RAUSP

54,1

68

The hypothesis $H 1 b$ sought to verify whether the participation in setting objectives increases the distributive justice perceived in MCS. The results do not support this assertion, i.e. the participation of the managers in setting objectives does not increase the distributive justice. Therefore, the empirical results do not confirm the theoretical premises, that participation can increase the chances of managers to receive fair rewards, as these will depend on the targets they have helped to define. Thus, participating in setting objectives is not directly linked to the remuneration received. This may indicate that companies do not necessarily reward managers fairly because they participate in setting goals and objectives. In this case, their remuneration would be more related to the improvement of economicfinancial performance than to participatory leadership. Possibly, participatory leadership would be more associated with personal satisfaction and work environment than with income distribution.

The second hypothesis ( $H 2 a$ and $H 2 b$ ) sought to verify whether the application of the controllability principle is significantly related to distributive justice and procedural justice. The results were not significant, i.e. when the company applies the controllability principle, its managers did not consider MCS to be fairer. This result is consistent with that of Beuren et al.'s (2015a), who, in replicating the research by Giraud et al. (2008) in the Brazilian environment, found out that managers are not concerned with the neutralization of uncontrollable factors. However, it contradicts the findings of Giraud et al. (2008) with French managers, which indicated that they wish to have internal factors controlled because of the perception of justice in this action. However, it is in line with studies conducted in Brazil. This suggests that these results are considered parsimoniously, once the environment of application of this concept has not been investigated, for example, it is possible that the extension of its application is not understood in its completeness.

The third hypothesis ( $H 3 a$ and $H 3 b$ ) sought to verify whether the quality of the feedback is significantly related to procedural and interactional justice of MCS. The results were significant at $p<0.01$, i.e. when managers receive high performance feedback MCS tends to be considered fair. According to Langevin and Mendoza (2012), an explanation for this is the fact that a well elaborated feedback is considered more consistent and precise, which complies with the procedural rules of Leventhal et al. (1980). Colquitt and Jackson (2006) mention that providing quality feedback encourages communication and leads to subordinates' favorable perception of their superiors. The quality of the feedback may also indicate that subordinates are valued and respected as members of the group.

The fourth hypothesis ( $H 4 a$ and $H 4 b$ ) tested the relationship between the use of multiple performance indicators and distributive and procedural justice. The results were significant at $p<0.01$, which indicates that the use of multiple measures of performance affects the distributive and procedural justice. In other words, managers consider that the use of multiple indicators increases the likelihood of more accurate assessments of their performance, whose argument is in line with Leventhal (1980), Burney et al. (2009) and Beuren et al. (2016a, 2016b, 2016c).

Tables VII and VIII were developed to test the set of hypotheses H5 and H6. Table VII presents the results of the indirect effect of the paths.

In addition to the indirect effect presented, Table VIII shows the results regarding the total effect of the paths.

In relation to the four dimensions of MCS and the budgetary slack $(H 5 a)$, the results indicated that setting objectives, multiple measures of performance and controllability principle were not statistically significant. On the other hand, feedback quality was significant at $p<0.01$, but the coefficient was positive. A negative coefficient was expected according to the proposition of the theoretical model, i.e. the quality of the feedback 


\begin{tabular}{|c|c|c|c|c|c|}
\hline Structural relationship & $\begin{array}{c}\text { Indirect } \\
\text { effect }\end{array}$ & $t$-Test & Hypothesis & $p$-value & control system \\
\hline Distributive justice $\rightarrow$ Data manipulation & -0.040 & 0.589 & $H 5 b$ and $H 6 b$ & 0.557 & \\
\hline Procedural justice $\rightarrow$ Budgetary slack & 0.018 & 0.260 & $H 5 a$ and $H 6 a$ & 0.795 & \\
\hline Procedural justice $\rightarrow$ Data manipulation & 0.120 & 1.588 & $H 5 b$ and $H 6 b$ & 0.113 & \\
\hline Distributive justice $\rightarrow$ Budgetary slack & 0.138 & 2.009 & $H 5 a$ and $H 6 a$ & 0.045 & \\
\hline Interactional justice $\rightarrow$ Budgetary slack & 0.357 & 3.933 & $H 5 a$ and $H 6 a$ & 0.000 & \\
\hline Interactional justice $\rightarrow$ Data manipulation & -0.275 & 2.715 & $H 5 b$ and $H 6 b$ & 0.007 & \\
\hline Setting objectives $\rightarrow$ Organizational commitment & 0.136 & 1.927 & $H 5 a$ and $H 6 a$ & 0.055 & \\
\hline Setting objectives $\rightarrow$ Trust in the superior & 0.019 & 0.400 & $H 5 b$ and $H 6 b$ & 0.689 & \\
\hline Setting objectives $\rightarrow$ Budgetary slack & 0.029 & 0.990 & $H 5 a$ and $H 6 a$ & 0.323 & \\
\hline Setting objectives $\rightarrow$ Data Manipulation & 0.033 & 1.193 & $H 5 b$ and $H 6 b$ & 0.234 & \\
\hline M.M. of Performance $\rightarrow$ Trust in the superior & 0.071 & 1.400 & $H 5 b$ and $H 6 b$ & 0.162 & \\
\hline M.M. of Performance $\rightarrow$ Budgetary slack & 0.057 & 1.648 & $H 5 a$ and $H 6 a$ & 0.100 & \\
\hline M.M. of Performance $\rightarrow$ Data manipulation & 0.016 & 0.540 & $H 5 b$ and $H 6 b$ & 0.590 & \\
\hline Controllability principle $\rightarrow$ Organizational commitment & -0.015 & 0.260 & $H 5 a$ and $H 6 a$ & 0.795 & \\
\hline Controllability principle $\rightarrow$ Trust in the superior & -0.030 & 0.826 & $H 5 b$ and $H 6 b$ & 0.409 & \\
\hline Controllability principle $\rightarrow$ Budgetary slack & -0.016 & 0.664 & $H 5 a$ and $H 6 a$ & 0.507 & \\
\hline Controllability principle $\rightarrow$ Data manipulation & 0.010 & 0.623 & $H 5 b$ and $H 6 b$ & 0.534 & \\
\hline M.M. of Performance $\rightarrow$ Organizational commitment & 0.164 & 2.743 & $H 5 a$ and $H 6 a$ & 0.006 & \\
\hline Quality of feedback $\rightarrow$ Organizational commitment & 0.247 & 2.608 & $H 5 a$ and $H 6 a$ & 0.010 & \\
\hline Quality of feedback $\rightarrow$ Trust in the superior & 0.444 & 4.960 & $H 5 b$ and $H 6 b$ & 0.000 & \\
\hline Quality of feedback $\rightarrow$ Budgetary slack & 0.241 & 3.722 & $H 5 a$ and $H 6 a$ & 0.000 & \\
\hline Quality of feedback $\rightarrow$ Data manipulation & -0.145 & 2.190 & $H 5 b$ and $H 6 b$ & 0.029 & PLS Results $-p$ \\
\hline \multicolumn{5}{|l|}{$\begin{array}{l}\text { Notes: P.S.: *Significance } p<0.05 ; * * \text { significance } p<0.01 \\
\text { Source: Research data }\end{array}$} & $\begin{array}{r}\text { coefficients - indire } \\
\text { effe }\end{array}$ \\
\hline
\end{tabular}

\begin{tabular}{lccll}
\hline & $\begin{array}{c}\text { Beta } \text { Total } \\
\text { Effect Total }\end{array}$ & $t$ Test & Hypothesis & P-value \\
Structural relationship & 0.231 & 1.669 & $H 5 a$ and $H 5 b$ & 0.095 \\
\hline Distributive j. $\rightarrow$ Commitment & 0.292 & 2.041 & $H 5 a$ and $H 5 b$ & $0.041^{*}$ \\
Procedural j. $\rightarrow$ Commitment & 0.238 & 1.652 & $H 5 a$ and $H 5 b$ & 0.099 \\
Interactional j. $\rightarrow$ Commitment & 0.148 & 1.112 & $H 5 a$ & 0.266 \\
Commitment $\rightarrow$ Budgetary slack & 0.316 & 2.806 & $H 5 b$ & $0.005^{* *}$ \\
Commitment $\rightarrow$ Data manipulation & 0.225 & 2.055 & $H 6 a$ and $H 6 b$ & $0.040^{*}$ \\
Distributive j. $\rightarrow$ Trust in the superior & -0.054 & 0.500 & $H 6 a$ and $H 6 b$ & 0.617 \\
Procedural j. $\rightarrow$ Trust in the superior & 0.697 & 6.104 & $H 6 a$ and $H 6 b$ & $0.000^{* *}$ \\
Interactional j. $\rightarrow$ Trust in the superior & 0.461 & 3.512 & $H 6 a$ & $0.000^{* *}$ \\
Trust $\rightarrow$ Budgetary slack & -0.503 & 4.107 & $H 6 b$ & $0.000^{* *}$ \\
Trust $\rightarrow$ Data manipulation & 0.029 & 0.966 & $H 5 a$ and $H 6 a$ & 0.334 \\
S. objectives $\rightarrow$ Budgetary slack & 0.033 & 1.126 & $H 5 b$ and $H 6 b$ & 0.260 \\
S. objectives $\rightarrow$ Data manipulation & 0.057 & 1.621 & $H 5 a$ and $H 6 a$ & 0.105 \\
M.M. of performance $\rightarrow$ Budgetary slack & 0.016 & 0.506 & $H 5 b$ and $H 6 b$ & 0.613 \\
M.M. of performance $\rightarrow$ Data manipulation & -0.016 & 0.669 & $H 5 a$ and $H 6 a$ & 0.504 \\
Controllability P. $\rightarrow$ Budgetary slack & 0.010 & 0.613 & $H 5 b$ and $H 6 b$ & 0.540 \\
Controllability P. $\rightarrow$ Data manipulation & 0.241 & 3.611 & $H 5 a$ and $H 6 a$ & $0.000^{* *}$ \\
Q. of Feedback $\rightarrow$ Budgetary slack & -0.145 & 2.293 & $H 5 b$ and $H 6 b$ & $0.022^{*}$ \\
Q. of Feedback $\rightarrow$ Data manipulation & & & & \\
& & & &
\end{tabular}

Notes: P.S.: *Significance $p<0.05$; ** significance $p<0.01$

Source: Research data

Table VIII.

PLS Results - path coefficients - total effect 
RAUSP

54,1

increases the perception of organizational justice, which leads to increase in organizational commitment and trust in the superior, reducing the budgetary slack (Langevin and Mendoza, 2012).

For the analysis of the paths, MCS does not reduce the budgetary slack, i.e. hypothesis $H 5 a$ is not confirmed. Regarding the budgetary slack, the analysis of the indirect path of the latent variable trust in the superior and budgetary slack present significance, but the coefficient proposed by the model is negative. It was hoped that the greater the trust in hierarchical superior the lower the propensity to manipulate data would be. The results showed that trust is related to data manipulation, but not necessarily to decrease in unethical behavior. It is argued that this result may find support in the tolerance to ambiguity in relation to the superior, observed in Beuren et al.'s (2016c) study.

Regarding commitment, statistical significance was not observed, which implies rejection of hypothesis $H 5 b$. These results indicate that the dimensions of the managerial control do not reduce the budgetary slack, i.e. the participation of the manager in setting objectives, the use of multiple measures of performance, the control of the variables that can influence the performance assessment and the quality of the feedback do not diminish the creation of budgetary slack, as proposed by Langevin and Mendoza (2012).

Another surprising result is that the latent variable trust in the superior shows significance opposed to what was expected, indicating that the greater the trust of the manager in his hierarchical superior, the greater the chances of creating budgetary slack. In addition to not conforming to the model proposed by Langevin and Mendoza (2012), this result suggests that the excess of proximity between manager and his superior can result in unethical behaviors. This result instigates reflections on the theoretical model and more empirical research, whether the trust in the superior is an antecedent or a consequent of creating organizational slack.

The sixth hypothesis (H6a and $H 6 b)$ investigated whether the organizational justice perceived in MCS reduces the propensity to create budgetary slack and manipulate data with increased trust in the superior and organizational commitment. The results indicate that three of the four dimensions of MCS tested did not present statistical significance, i.e. setting objectives, controllability principle and multiple measures of performance are not related to data manipulation. These results do not corroborate that the success of MCS will depend on the organizational commitment, the trust between subordinate and superior and the perceived organizational justice in the system (Chenhall, 2003). However, the dimension quality of feedback presents statistical significance, in addition to signaling through its coefficient that it also reduces the manipulation of data, i.e. a quality feedback can help the company fight data manipulation.

Regarding commitment, the results surprisingly indicate that there is a relationship between organizational commitment and data manipulation. The coefficient was expected to be negative by the model, but it was positive, indicating that commitment increases data manipulation, not the opposite as indicated by Langevin and Mendoza (2012). It is argued that the investigated companies need to interact in the improvement of the organizational commitment related to MCSs, as the theory indicates that the more committed with MCSs, the less propensity managers have to manipulate the data. The relationship between trust and data manipulation points out that the higher the trust, the lower the manager's propensity to manipulate the data, which is in line with the theoretical proposition of Langevin and Mendoza (2012). 


\section{Conclusions}

\subsection{Theoretical implications}

The study aimed to validate the theoretical model proposed by Langevin and Mendoza (2012), testing the theoretical hypotheses formulated by the authors, which they did not test empirically. Descriptive statistics based on the answers to the research instrument, composed of 41 assertions to test the theoretical hypotheses of Langevin and Mendoza's (2012) study, show that the 102 respondents presented certain linearity in the levels of concordance in relation to the assertives, varying from medium to high. The SEM (PLS-PM) technique was used to test the hypotheses.

In hypothesis $H 1 a$ it was verified whether the participation in setting objectives is significantly related to procedural justice. The results indicated that when managers participate in setting objectives, business processes are considered fair. The result is consistent with that observed in Langevin and Mendoza (2012). In hypothesis $H 1 b$ it was verified whether the participation in the setting the objectives increases the distributive justice perceived in MCS, but the results did not support this statement.

In the second hypothesis ( $H 2 a$ and $H 2 b)$, it was investigated whether the application of the controllability principle is significantly related to distributive and procedural justice. The results were not significant, i.e. when the company applied the controllability principle, its managers did not consider the MCS to be fairer. This result contradicts the theoretical assumption of Langevin and Mendoza (2012), that when managers are assessed only on the basis of what they can control, MCS is perceived as fair.

In the third hypothesis ( $H 3 a$ and $H 3 b)$ it was analyzed whether the quality of the feedback is significantly related to procedural and interactional justice of MCS. The results were significant, corroborating with the literature (Leventhal et al., 1980; Colquitt and Jackson, 2006; Paiva, 2015). In the fourth hypothesis ( $H 4 a$ and $H 4 b)$ it was verified whether multiple performance indicators are significantly related to distributive and procedural justice. The results were significant and converge with the premises of Leventhal (1980) and Burney et al. (2009).

Regarding the hypothesis $H 5 a$, the results indicated that setting objectives, multiple measures of performance and controllability principle are not statistically significant. The quality of the feedback was significant, but with coefficient opposed to what was expected. Analyzing the paths, MCS does not reduce budgetary slack, and it is not possible to confirm hypothesis $H 5 a$. The sixth hypothesis ( $H 6 a$ and $H 6 b$ ) examined whether the organizational justice perceived in MCS reduces the propensity to create budgetary slack and manipulate the data with increased trust in the superior and organizational commitment. In the test results, only the dimension quality of feedback presented statistical significance, besides signaling with its coefficient that it reduces data manipulation.

In summary, the results of the research demonstrate that participation in setting objectives increases procedural justice, i.e. the process of participating in setting objectives is considered fair, but this is not closely related to the remuneration of managers, a fact advocated by literature $(H 1 b)$. Likewise, disregarding aspects uncontrolled by managers in performance assessment does not lead to the perception of procedural and distributive justice $(H 2 a$ and $H 2 b)$. However, quality of feedback leads to the perception that MCS is fair ( $H 3 a$ and $H 3 b)$, indicating that subordinates feel valued and respected as members of the group. Multiple measures of performance present similar results, i.e. there is a perception of distributive and procedural justice when it is used by the company. 
RAUSP

54,1

\subsection{Practical implications}

The research carried out with managers of large Brazilian companies, which investigated MCS's dimensions (participation in the setting objectives, application of the controllability principle, use of multiple performance indicators and quality of feedback) increase the perception of organizational justice and reduce unhealthy behaviors, has shown that the only variable that positively interferes with the reduction of unethical behaviors is the quality of feedback. Therefore, from the theoretical framework of Langevin and Mendoza (2012), regarding the effects of MCS on unethical behaviors through perceived organizational justice, organizational commitment and supervisor trust, only quality of feedback interferes in the reduction of the unethical behaviors creation of budgetary slack and data manipulation.

These results differ from those presented by Buzzi et al. (2014), who identified a relationship between budgetary slack and budgetary participation. They are in accordance with the study by Chong and Strauss (2017), which points to a decrease in the propensity to create budgetary slack when the budget is considered participatory and the perception of procedural justice is positive. Thus, although the explanation has been partial, with the validation of only one of the four elements of the MCS model of Langevin and Mendoza (2012), somehow this research can contribute to the warning of Cugueró-Escofet and Rosanas (2017) about the relevance of understanding the dysfunctional effects of measurement and incentives systems.

\subsection{Limitations and/or future research studies}

Participating in setting objectives, using multiple measures of performance and controlling factors related to performance evaluation may be linked to greater perception of organizational justice. However, other uninvestigated factors may interfere and contribute to the reduction of unethical behavior, such as budgetary slack and data manipulation, as the only variable that indicated interference in this reduction was quality of feedback. The fact that not all hypotheses have been confirmed instigates further research. In this sense, it is recommended to replicate the study in other contexts to verify whether the results are similar to validate the theoretical model of Langevin and Mendoza (2012) and to look for possible ways to overcome those effects considered dysfunctional in organizations.

\section{References}

Ackroyd, S. and Thompson, P. (1999), Organizational Misbehaviour, Sage, London.

Anthony, R.N. (1965), Planning and Control Systems: A Framework for Analysis, Harvard Business School, Boston.

Anthony, R.N. and Govindarajan, V. (2006), Sistemas de Controle Gerencial, Atlas, São Paulo.

Beuren, I.M., Altoé, S.M.L. and Dal Vesco, D.G. (2016a), "Percepção de justiça e comportamento de cidadania organizacional: um estudo na perspectiva do sistema de mensuração de desempenho estratégico", Cuadernos de Administración, Vol. 28n No. 51, pp. 133-157.

Beuren, I.M., Amaro, H.D. and Silva, P. Y.C. (2015a), "Percepção dos gestores em relação ao princípio da controlabilidade Para o alcance da justiça organizacional”, REAd. Revista Eletrônica de Administração (Porto Alegre), Vol. 21 No. 2, pp. 378-405.

Beuren, I.M., Beck, F. and Popik, F. (2015b), "Do shared interests affect the accuracy of budgets?", Revista Contabilidade and Finanças, Vol. 26 No. 67, pp. 11-26.

Beuren, I.M., Kreuzberg, F. and Franz, L. (2016c), "Percepção de justiça processual na avaliação de desempenho: uma análise à luz da incerteza e da tolerância à ambiguidade", Advances in Scientific and Applied Accounting, Vol. 9 No. 1, pp. 3-21. 
Beuren, I.M., Klein, L., Lara, F.L. and Almeida, L.B. (2016b), "Percepção de justiça nos sistemas de controle gerencial aumenta comprometimento e confiança dos gestores?”, Revista de Administração Contemporânea, Vol. 20 No. 2, pp. 216-237.

Bido, D.S., Silva, D., Souza, C.A. and Godoy, A.S. (2010), "Mensuração com indicadores formativos nas pesquisas em administração de empresas: Como lidar com a multicolinearidade entre eles? ”, Administração: Ensino e Pesquisa, Vol. 11 No. 2, pp. 245-269.

Bollen, KA. and Long, J.S. (1992), "Tests for structural equation models: introduction", Sociological Methods and Research, Vol. 21 No. 2, pp. 123-131.

Burkert, M., Fischer, F.M. and Schäffer, U. (2011), "Application of the controllability principle and managerial performance: the role of role perceptions", Management Accounting Research, v. Vol. 22 No. 3, pp. 143-159.

Burney, L.L., Henle, C.A. and Widener, S.K. (2009), “A path model examining the relations among strategic performance measurement system characteristics, organizational justice, and extraand in-role performance", Accounting, Organizations and Society, Vol. 34 Nos 3/4, pp. 305-321.

Buzzi, D.M., Santos, V., Beuren, I.M. and Faveri, D.B. (2014), "Relação da folga orçamentária com participação e ênfase no orçamento e assimetria da informação", Revista Universo Contábil, Vol. 10 No. 1, pp. 6-27.

Campana, A.N., Tavares, M.C. and Silva, D. (2009), "Modelagem de equações estruturais: apresentação de uma abordagem estatística multivariada Para pesquisas em educação física”, Motricidade, Vol. 5 No. 4, pp. 59-80.

Chenhall, R.H. (2003), "Management control systems design within its organizational context: findings from contingency-based research and directions for the future", Accounting, Organizations and Society, Vol. 28 Nos 2/3, pp. 127-168.

Chong, V.K. and Strauss, R. (2017), "Participative budgeting: the effects of budget emphasis, information asymmetry and procedural justice on slack-additional evidence", Asia-Pacific Management Accounting Journal, Vol. 12 No. 1, pp. 181-220.

Cohen, J. (1988), Statistical Power Analysis for the Behavioral Sciences, 2nd ed. Psychology Press, New York, NY.

Cohen-Charash, Y. and Spector, P.E. (2001), "The role of justice in organizations: a meta-analysis", Organizational Behavior and Human Decision Processes, Vol. 86 No. 2, pp. 278-321.

Colquitt, J.A. (2001), "On the dimensionality of organizational justice: a construct validation of a measure", Journal of Applied Psychology, Vol. 86 No. 3, pp. 386-400.

Colquitt, J.A. and Jackson, C.L. (2006), "Justice in teams: the context sensitivity of justice rules across individual and team contexts", Journal of Applied Social Psychology, Vol. 36 No. 4, pp. 868-899.

Colquitt, J.A., Conlon, D.E., Wesson, M.J., Porter, C.O.L.H. and NG, K.Y. (2001), "Justice at the millennium: a meta-analytic review of 25 years of organizational justice research", Journal of Applied Psychology, Vol. 86 No. 3, pp. 425-445.

Condé, R.A.D. (2013), "Fraudes corporativas: um estudo de casos múltiplos à luz da teoria dos escândalos corporativos 101f”, Dissertação (Mestrado em Ciências Contábeis), Faculdade de Administração e Finanças da UERJ, Rio de Janeiro.

Cugueró-Escofet, N. and Rosanas, J.M. (2017), "The ethics of metrics: overcoming the dysfunctional effects of performance measurements through justice”, Journal of Business Ethics, Vol. 140 No. 4, pp. 615-631.

Cyert, R.M. and March, J. (1963), A Behavioral Theory of the Firm, Prentice Hall, Englewood Cliffs, NJ.

Dal Vesco, D.G., Beuren, I.M. and Popik, F. (2016), "Percepção de justiça na avaliação na avaliação de desempenho e satisfação do trabalho”, Enfoque: Reflexão Contábil, Vol. 35 No. 3, pp. 121-138.

Davis, S., Dezoort, F.T. and Kopp, L.S. (2006), "The effect of obedience pressure and perceived responsibility on management accountants' creation of budgetary slack", Behavioral Research in Accounting, Vol. 18 No. 1, pp. 19-35. 
RAUSP

54,1

Dunk, A.S. (1993), "The effect of budget emphasis and information asymmetry on the relation between budgetary participation and slack", The Accounting Review, Vol. 68 No. 2, pp. 400-410.

Faul, F., Erdfelder, E., Buchner, A. and Lang, A.-G. (2009), "Statistical power analyses using G*power 3.1: tests for correlation and regression analyses", Behavior Research Methods, Vol. 41 No. 4, pp. 1149-1160.

Fávero, L., Belfiore, P., Silva, F. and Cham, B. (2009), Análise de Dados: modelagem Multivariada Para Tomada de Decisões, Campus, São Paulo.

Flamholtz, E. (1979), "Organizational control systems as a managerial tool”, California Management Review, Vol. 22 No. 2, pp. 50-59.

Folger, R. and Greenberg, J. (1985), "Procedural justice: an interpretive analysis of personnel systems", in Rowland, K. and Ferris, G. (Eds). Research in Personnel and Human Resources Management, JAI Press, Greenwich, CT., Vol. 3. pp. 141-183.

Folger, R.G. and Cropanzano, R. (1998), Organizational Justice and Human Resource Management, Sage, London.

Folger, R.G. and Konovsky, M.A. (1989), "Referent cognitions and task decision autonomy: beyond equity theory", Journal of Applied Psychology, Vol. 74 No. 2, pp. 293-299.

Fortin, M. (2008), "Perspectives on organizational justice: concept clarification, social context integration time and links with morality", International Journal of Management Reviews, Vol. 10 No. 2, pp. 93-126.

Gaski, J.F. and Nevin, J.R. (1985), “The differential effects of exercised and unexercised power sources in a marketing channel", Journal of Marketing Research, Vol. 22 No. 2, pp. 130-142.

Giraud, F., Langevin, P. and Mendoza, C. (2008), "Justice as a rationale for the controllability principle: a study of managers opinions", Management Accounting Research, Vol. 19 No. 1, pp. 32-44.

Greenberg, J. (1993), “The intellectual adolescence of organizational justice: you've come a long way, maybe”, Social Justice Research, Vol. 6 No. 1, pp. 135-148.

Hair, J.F., Ringle, C.M. and Sarstedt, M. (2011), "PLS-SEM: indeed a silver bullet”, Journal of Marketing Theory and Practice, Vol. 19 No. 2, pp. 139-152.

Hair, J.F., Jr, Anderson, R.E., Tatham, R.L. and Black, W.C. (2005), Análise Multivariada de Dados, Bookman, Porto Alegre.

Hartmann, F. and Slapnicar, S. (2009), "How formal performance evaluation affects trust between superior and subordinate managers", Accounting, Organization and Society, Vol. 34 Nos 6/7, pp. $722-737$.

Henri, J.F. (2006), "Management control systems and strategy: a resource-based perspective", Accounting, Organizations and Society, Vol. 31 No. 6, pp. 529-558.

Hopwood, A.G. (1972), "An empirical study of the role of accounting data in performance evaluation”, Journal of Accounting Research, Vol. 10, pp. 156-182.

Hox, J.J. and Bechger, T.M. (1998), "An introduction to structural equation modeling”, Family Science Review, Vol. 11 Nos. 6/7, pp. 354-373.

Jesus, R.G. and Rowe, D.E.O. (2015), "Percepção de políticas de gestão de pessoas e comprometimento organizacional: o papel mediador da percepção de justiça organizacional”, Tourism and Management Studies, Vol. 11 No. 2, pp. 211-218.

Jones, T.M. (1991), "Ethical decision making by individuals in organizations: an issue-contingent model", Academy of Management Review, Vol. 16 No. 2, pp. 366-395.

Langevin, P. and Mendoza, C. (2012), "How can management control system fairness reduce managers' unethical behaviours?", European Management Journal, Vol. 31 No. 3, pp. 209-222.

Lavarda, C.E.F. and Fank, O.L. (2014), "Relação da assimetria da informação, da participação orçamentária e do risco na criação da folga orçamentária”, Contextus - Revista Contemporânea de Economia e Gestão, Vol. 12 No. 1, pp. 81-110. 
Leventhal, G.S. (1980), "What should be done with equity theory? New approaches to the study of fairness in social relationships", in Gergen, K., Greenberg, M. and Willis, R. (Eds), Social Exchange: New Advances in Theory and Research, Plenum Press, New York, NY, pp. 27-55.

Leventhal, G.S., Karuza, J. and Fry, W.R. (1980), "Beyond fairness: a theory of allocation preferences”, in Mikula, G. (Ed.), Justice and Social Interaction: experimental and Theorical Contributions from Psychological Research, Springer-Verlag, New Yourk. pp. 167-218.

Libby, T. (2003), "The effect of fairness in contracting on the creation of budgetary slack", Advances in Accounting Behavioral Research, Vol. 6 No. 1, pp. 145-169.

Little, H.T., Magner, N.R. and Welker, R.B. (2002), "The fairness of formal budgetary procedures and their enactment relationships with managers' behavior", Group and Organization Management, Vol. 27 No. 2, pp. 209-225.

López, M.A.L., Stammerjohan, W.W. and Mcnair, F.M. (2007), "Differences in the role of job-relevant information in the budget participation-performance relationship among US and Mexican managers: a question of culture or communication", Journal of Management Accounting Research, Vol. 19 No. 1, pp. 105-136.

Klem, L. (2006), "Structural equation modeling”, in Grimm, L.G. and Yarnold, P.R. (Eds), Reading and Understanding More Multivariate Statistics, American Psychological Association, Washington, DC, pp. 227-260.

Maia, L.G. (2013), "Percepção de comportamentos de retaliação: frequência e avaliação de justiça", Diaphora, Vol. 13 No. 1, pp. 45-52.

Merchant, K.A. (1985), "Budgeting and the propensity to create budgetary slack", Accounting, Organizations and Society, Vol. 10 No. 2, pp. 201-210.

Merchant, K.A. and Rockness, J. (1994), "The ethics of managing earnings: an empirical investigation”, Journal of Accounting and Public Policy, Vol. 13 No. 1, pp. 79-94.

Merchant, K.A. and Van Der Stede, W.A. (2000), "Ethical issues related to 'results-oriented' management control systems", Research on Accounting Ethics, Vol. 6, pp. 153-169.

Merchant, K.A. and Van Der Stede, W.A. (2007), Management Control Systems: Performance Measurement, Evaluation and Incentives, Harlow, Essex.

Mikula, G. (1980), Justice and Social Interaction: experimental and Theorical Contributions from Psychological Research, Springer-Verlag, New York.

Mowday, R.T., Steers, R.M. and Porter, L.W. (1979), “The measurement of organizational commitment”, Journal of Vocational Behavior, Vol. 14 No. 2, pp. 224-247.

Nouri, H. and Parker, R.J. (1996), "The effect of organizational commitment on the relation between budgetary participation and budgetary slack", Behavioral Research in Accounting, Vol. 8 No. 1, pp. 74-90.

Omar, A. (2006), "Justicia organizacional, individualismo-colectivismo y estrés laboral", Psicologia y Salud, Vol. 16 No. 2, pp. 207-217.

Onsi, M. (1973), "Factor analysis of behavioral variables affecting budgetary slack", The Accounting Review, Vol. 48 No. 3, pp. 535-548.

Paiva, M.J.A.C. (2015), "Efeito dos julgamentos de justiça e do feedback no salário de reserva", Dissertação (Mestrado em Psicologia Aplicada), Universidade do Minho, Portugal.

Pasquali, L. (2003), Psicometria: teoria Dos Testes na Psicologia e na Educação, Vozes, Petrópolis.

Podsakoff, P.M. and Organ, D.W. (1986), "Self-reports in organizational research: problems and prospects", Journal of Management, Vol. 12 No. 4, pp. 531-544.

Podsakoff, P.M., Mackenzie, S.B., Lee, J.Y. and Podsakoff, N.P. (2003), "Common method biases in behavioral research: a critical review of the literature and recommended remedies", Journal of Applied Psychology, Vol. 88 No. 5, pp. 879-903. 
RAUSP

54,1

Rego, A. (2002), "Comprometimento afectivo dos membros organizacionais: o papel das percepções de justiça”, Revista de Administração Contemporânea, Vol. 6 No. 2, pp. 209-241.

Rego, A. and Souto, S. (2004), "A percepção de justiça como antecedente do comprometimento organizacional: um estudo luso-brasileiro", Revista de Administração Contemporânea, Vol. 8 No.1, pp. 151-177.

Silva, S.D., JR. and Costa, F.J. (2014), "Mensuração e escalas de verificação: uma análise comparativa das escalas de likert e phrase completion”, PMKT. Revista Brasileira de Pesquisas de Marketing, Opinião e Mídia, Vol. 15, pp. 1-16.

Simons, R. (1995), Levers of Control, Harvard Business School Publishing, Boston.

Sotomayor, A.M.S.B. (2007), "Avaliação de desempenho e compromisso organizacional: a perspectiva da justiça organizacional”, Revista Universo Contábil, Vol. 3 No. 3, pp. 87-100.

Staley, A.B. and Magner, N.R. (2007), "Budgetary fairness, supervisory trust, and the propensity to create budgetary slack: testing a social exchange model in a government budgeting context", Advances in Accounting Behavioral Research, Vol. 10 No. 1, pp. 159-182.

Wentzel, K. (2004), "Do perceptions of fairness mitigate managers use of budgetary slack during asymmetric information conditions?", Advances in Management Accounting, Vol. 13 No. 1, pp. 223-244.

Whitener, E.M., Brodt, S.E., Korsgaard, M.A. and Werner, J.M. (1998), "Managers as initiators of trust: an exchange relationship framework for understanding managerial trustworthy behavior", Academy of Management Review, Vol. 23 No. 3, pp. 513-530.

Widener, S.K. (2006), "Human Capital, pay structure, and the use of performance measures in bonus compensation", Management Accounting Research, Vol. 17 No. 2, pp. 198-221.

\section{Corresponding author}

Ilse Maria Beuren can be contacted at: ilse.beuren@gmail.com

Associate editor: Luiz Paulo Fávero

For instructions on how to order reprints of this article, please visit our website: www.emeraldgrouppublishing.com/licensing/reprints.htm Or contact us for further details: permissions@emeraldinsight.com 